JURNAL BASICEDU

Research \& Learning in Elementary Education

https://jbasic.org/index.php/basicedu/index

\title{
Metode Problem Solving Untuk Meningkatkan Hasil Belajar Matematika di Sekolah Dasar
}

\author{
Cahyo Dwi Andita ${ }^{1}$, Taufina ${ }^{2}$ \\ Universitas Negeri Padang, Sumatera Barat, Indonesia ${ }^{1,2}$ \\ Email: $\underline{\text { cahyodwiandita23101996@gmail.com }}{ }^{1}$, taufina@ fip.unp.ac.id ${ }^{2}$
}

\begin{abstract}
Abstrak
Rendahnya hasil belajar siswa pada pembelajaran soal cerita matematika yang disebabkan oleh pemilihan metode pembelajaran yang kurang tepat merupakan hal yang melatarbelakangi penelitian ini. Pemerolehan pembelajaran pada pokok bahasan soal cerita melalui metode Problem Solving merupakan tujuan dasar yang akan dicapai. Seluruh siswa kelas III SDN 03 Koto Salak Kabupaten Dharmasraya adalah subjeknya. Jenis penelitian yang digunakan adalah Penelitian Tindakan Kelas dengan menggunakan model Kemis Mc. Taggart. Pemerolehan data penelitian menunjukkan bahwa penggunaan metode Problem Solving dapat meningkatkan hasil belajar siswa pada soal cerita. Hasil tes pada siklus I nilai rata-ratanya adalah 72,29 dengan persentase ketuntasan 58,80\% kemudian mengalami peningkatan pada sikus ke-dua menjadi 86,29 dengan persentase ketuntasan klasikal mencapai 82,35\%.
\end{abstract}

Kata Kunci: Problem solving, hasil belajar, soal cerita

\begin{abstract}
The research is conducted due to the students' low achievements in accomplishing math story problems caused by selection of inappropriate learning method. The research aimed at improving students' achievements in accomplishing Math Story Problems by using Problem Solving method. Subjects of the research were class III elementary students of SDN 03 Koto Salak, Dharmasraya regency. This is a Classroom Action research by adopting Mc.Taggart scheme. The finding of the research revealed that the use of Problem solving can improve the students' learning achievements in accomplishing math story problem significantly. In cycle I, mean of test score was 72.29 and improved at 86.29 in cycle II. Meanwhile classical learning completeness in cycle I was $58.80 \%$ and improved at $82.35 \%$ in cycle II.
\end{abstract}

Keywords: Problem Solving, learning outcomes, story problem

Copyright (c) 2020 Cahyo Dwi Andita, Taufina

$\triangle$ Corresponding author:

Address : -

Email : cahyodwiandita23101996@gmail.com

ISSN 2580-3735 (Media Cetak)

Phone :ISSN 2580-1147 (Media Online)

DOI: https://doi.org/10.31004/basicedu.v4i3.397 


\section{PENDAHULUAN}

Salah satu landasan berdirinya sebuah pendidikan yakni mengacu kepada sebuah kurikulum. Kurikulum adalah sekumplan rancangan dan peraturan terkait tujuan, isi/conten, materi pelajaran dan langkah-langkah pembelajaran yang dianut sebagai pegangan dalam menerapkan langkah pembelajaran untuk menggapai tujuan pendidikan yang telah ditetapkan (BSNP 2006). Layaknya sebuah pendidikan, kurikulum juga memiliki tujuan yang akan diwujudkan dalam proses pembelajaran matematika. Tujuan tersebut yakni untuk membentuk pembelajar memiliki kemampuan dan ketrampilan dalam mengatasi problematika kehidupan yang dituangkan dalam soal-soal matematika, yamg kemudian dapat merancang dan mengetahui cara penyelesaian soal matematika tersebut (Depdiknas 2006).

Matematika adalah muatan pembelajaran yang sangat perlu dan mutlak dipelajari di sekolahsekolah formal, sebab dengan pembelajaran matematika mampu mengembangkan kemempuan bernalar dan berpengaruh besar terhadap penyelesaian masalah yang ada kaitannya dengan kehidupan sehari-hari, dan mendukung kemajuan iptek (Anugraheni, 2019). Menurut (PERMENDIKNAS No 22 Tahun 2006) "pemberian pembelajaran matematik di tingkat dasar memiliki misi untuk membentuk pembelajar yang mempunyai keahlian dalam memahami konsep matematika, dan menerapkan ilmu tersebut secara tepat" selanjutnya, kegiatan "membiasakan pembelajar untuk bernalar menggunakan pola pikir dan logika agar trampil dalam memecahkan persoalan-persoalan yang diberikan dalam bentuk latihan pemecahan soal matematika merupakan tujuan dari membelajarakan ilmu matematik di tingkat dasar" (Imelda, 2018).
Pokok bahasan yang termuat dalam pelajaran matematika yang perlu diilhami dan dikuasai oleh siswa SD ialah pembelajaran soal cerita matematika, sebab pengalaman yang diperoleh pembelajar melalui kegiatan memecahkan permasalahan akan membentuk pembelajar yang trampil dan tangguh dalam mengatasi permasalahan yang ditemuai dalam kehidupan nyata pembelajar (Taufina et al., 2019). Landasan pokok dalam pembelajaran matematika ialah kemampuan siswa dalam memecahkan permasalahan (Hidayat \& Sariningsih, 2018). Seluruh siswa SD dituntut untuk memiliki kemampuan memecahkan masalah untuk membekali siswa agar terbiasa berpikir pada level tinggi dalam mengatasi kesukaran disetiap pengambilan keputusan atas masalah yang dihadapi baik yang ditemuai dalam persoalan matematik maupun yang berhubungan dengan permasalahan sosial (Fitri, 2016). Senada dengan hal tersebut Husna \& Burais, (2019) menyatakan bahwa "pemecahan masalah dapat diartikan sebagai sekumpulan langkah yang dipakai seseorang untuk menanggulangi kesukaran yang dihadapi dalam mencapai target yang diinginkan dalam belajar".

Berdasarkan teori di atas, siswa kelas III SD, diharapkan dapat memiliki keahlian dalam menyelesaikan soal cerita matematika serta dapat mengembangkan kemampuannya dalam mengolah pola pikir dan logika dalam bentuk latihan pemecahan soal dan menunjukkan hasil belajar matematika yang baik. Namun pada kenyataannya, data yang diperoleh peneliti dalam observasi di SDN 03 Koto Salak khususnya kelas IIIb menunjukkan bahwa, sebagian besar siswa menganggap sulit, dan merasa jenuh saat mempelajari soal cerita matematika, serta ditemukan data yang menunjukkan hasil belajar matematikanya rendah. 
Tabel 1. Persentase pencapaian belajar siswa kelas IIIb

\begin{tabular}{|c|c|c|c|c|c|}
\hline KKM & $\begin{array}{c}\text { Jumlah } \\
\text { Siswa }\end{array}$ & $\begin{array}{c}\text { Jumlah } \\
\text { Siswa } \\
\text { yang } \\
\text { Tun } \\
\text { Tas }\end{array}$ & $\begin{array}{c}\text { Jumlah } \\
\text { Siswa } \\
\text { yang } \\
\text { Belum } \\
\text { Tuntas }\end{array}$ & $\begin{array}{c}\text { Persen } \\
\text { tase } \\
\text { Siswa } \\
\text { yang } \\
\text { Tuntas }\end{array}$ & $\begin{array}{c}\text { Persen- } \\
\text { tase } \\
\text { Siswa } \\
\text { yang } \\
\text { Belum } \\
\text { Tuntas }\end{array}$ \\
\hline 75 & 17 & 6 & 11 & $35,30 \%$ & $64,70 \%$ \\
\hline
\end{tabular}

Sumber: Dokumen Wali Kelas III SDN 03 Koto Salak Tahun Ajaran 2017/2018

Berdasarkan Tabel 1. dapat diketahui bahwa dari jumlah siswa kelas III B yakni 17 siswa, hanya terdapat $35,30 \%$ atau setara dengan 6 siswa saja yang tuntas dan memenuhi KKM pada pembahasan soal cerita matematika. Batas nilai minimum yang telah ditentukan untuk dipakai di sekolah tersebut adalah 75. Maka dari itu, sangat jauh dari kata optimal yang patut untuk menggambarkan kondisi ataupun keadaan siswa dalam kemampuannnya untuk menyelesaikan persoalan cerita pada pembelajaran matematika.

Salah satu metode yang mampu memberikan dampak positif terhadap peningkatan hasil belajar siswa pada soal cerita matematika adalah metode problem solving. Djamarah (2010) mengungkapkan bahwasannya "di dalam metode problem solving (pemecahan masalah) tidak hanya menuangkan tentang bagaimana langkah-langkah mengajar, tetapi juga mengajarkan tentang bagaimana berpikir dalam memecahkan suatu masalah menggunakan beberapa metode yang diawali dengan memahami masalah, mencari data/keterangan menguji kebenaran jawaban dan sampai kepada penarikan kesimpulan”, selanjutnya Murray, Olivier dan Human (dalam Huda, 2017) berpendapat bahwa "Problem Solving Learning (Pembelajaran pemecahan masalah) adalah sebagai salah satu cara pembelajaran yang mengangkat maslah sebagai topik utamanya". Metode Problem Solving Learning lebih banyak diterapkan pada pelajaran matemamtika dan lebih menekankan pada praktik/penerapan (Huda, 2017). Semakin sering siswa melakukan praktik atau latihan dalam menganalisis soal, maka akan semakin mudah dan terbiasa menghadapai penyelesaian soal cerita matematika serta dapat meningkatkan prestasi belajar siswa ke arah yang lebih baik lagi. Keterlibatan aktif seorang siswa dalam pembelajaran dan bimbingan dari seorang pendidik merupakan ciri darimetode problem solving (Djamarah, 2010).

Orientasi dalam metode problem solving, peran guru lebih banyak ditekankan untuk menjadi motivator dan fasilitator yang akan memberikan bantuan siswa dalam membandingkan cara/metode satu sama lain, mencarikan solusi permasalahan dan seterusnya, sehingga dengan metode problem solving (pemecahan masalah) siswa dapat terlibat langsung kedalam pembelajaran yang akan memberikan kesan mendalam bagi pembelajran siswa di kelas. Siswa dapat menganalisis masalah pada soal cerita matematika dengan cara menuliskan apa yang diketahui dan yang ditanyakan dalam soal cerita tersebut. Apabila sudah ditemukan maka siswa dapat membuat operasi hitung matematikanya serta dapat memecahkan persoalan tersebut. Kemudian daripada itu semua kemempuan pembelajar juga dapat dilatih dalam menghasilkan pemikiran yang kritis demi pencapaian suatu mufakat untuk jalan keluar masalah.

Bertolak dari hasil observasi yang dilakukan peneliti dengan walikelas III SDN 03 Koto Salak, menginformasikan bahwa ketidakmampuan pembelajar dalam penyelesaian persoalan berbasis masalah matematika dikarenakan peserta didik tersebut belum memahami langkah-langkah penyelesaian persoalan cerita tersebut dan merasa kesulitan saat mengubah kalimat bahasa kedalam operasi hitung matematika. Hal ini dikarenakan guru dalam megajarkan pokok bahasan 
pembelajaran penyelesaian persoalan cerita matematika tidak menggunakan metode problem solving, alasannya karena guru tersebut kurang memahami langkah-langkah dari metode problem solving tersebut. Padahal seharusnya seorang guru yang mengajarkan matematika juga harus memiliki kompetensi dalam bidang matematika dan memiliki percaya diri yang kuat agar mampu menghantarkan peserta didik pada keberhasilan pembelajaran (Daharnis et al., 2019). Berdasarkan hal tersebut, maka dapat disimpulkan bahwasanya pemilihan metode yang diterapkan oleh guru selama ini dianggap belum mampu menjawab pokok permasalahan dalam pembelajaran matematika yang dialami oleh siswa selama ini.

Pada kegiatan penyampaian pokok bahasan soal cerita, hendaknya pendidik dapat menerapkan metode problem solving agar si pembelajar terbiasa dalam memecahkan masalah-masalah yang dihadapinya, dan memiliki kemampuan serta keterampilan dalam menyelesaiakan soal cerita matematika dengan mengikuti tahapan dari metode problem solving yang meliputi; memahami suatu problematika, mencari fakta/keterangan, menentukan jawaban sementara dan menguji kebenaran jawaban sampai kepada menarik kesimpulan. Menurut Uyani, (2016) dalam penelitiannya menyimpilkan bahwa bahwa pembelajran yang dilaksanakan dengan mengikuti metode problem solving kemampuan HOT seluruh siswa kelas VI SDN Banyu Landas pada materi geometri meningkat dalam kategori sangat baik. Aktivitas guru dan siswa dalam kegiatan pembelajaran menggunakan model Problem Solving pada materi perubahan geometri juga meningkat dalam kategori baik. Selanjutnya menurut penelitan yang dilakukan oleh Pagarra, (2016) mengungkapkan bahwa pemerolehan skor hasil belajar siswa setelah menggunakan metode problem solving memperoleh skor rata-rata 84,28 dan bahkan ada salah satu siswa yang memperoleh nilai maksimum yaitu 100 dan nilai terendahnya 40. Dalam penelitiannya dijelaskan ada 6 siswa atau setara $21 \%$ yang tidak tuntas dan 22 siswa ataau setara $79 \%$ yang telah tuntas hasil belajarnya pada pembelajaran matematika. Sehingga secara keseluruhan pembelajaran dapat dikatakan sudah tercapai, karena lebih dari $70 \%$ yaitu $79 \%$.

Senada dengan hal tersebut Sakadius et al., (2017) dalam peneliatannya mengungkapkan bahwa beradasarkan data yang telah terkumpul dapat diketaui bahwa dalam mengerjakan soal cerita matematika menggunakan metode problem solving pada pembelajaran matematika keahlian pembelajar kelas IV SDN 21 Kubu setiapsiklus meningkat. Persentase peningkatan dari siklus yang pertama ke siklus yang ke-dua mencapai 7,69 $\%$ yakni dari $63,85 \%$ menjadi $71,54 \%$, dan besar persentase meningkatnya siklus ke-dua ke siklus ke-tiga adalah $4,61 \%$ yakni dari $71,54 \%$ menjadi $76,15 \%$. Selanjutnya, diperkuat lagi dengan pemerolehan data penelitian yang dilakuan oleh Sitorus selama dua siklus yang menginformasikan terkait adanya pelaksanaan pembelajaran soal cerita menggunakan metode problem solving dapat meningkatkan pemerolehan belajar yang mencakup tiga ranah pembelajaran. Hasil rata-rata kemampuan awal sebelum diberikan tindakan adalah 50,90 dengan persentase $12,82 \%$ atau setara dengan 5 orang saja yang tuntas dalam pembelajaran. Rata-rata hasil belajar siswa pada siklus satu setelah mendapat tindakan menggunakan metode problem solving meningkat menjadi 66,40 dengan persentase 33,33\% atau setara dengan 13 orang yang tuntas dalam pembelajaran soal cerita matematika, sehingga terjadi peningkatan $20,51 \%$ dari pembelajaran sebelum adanya tindakan. Pada siklus ke-II ratarata hasil belajar siswa meningkat kembali menjadi 77,50 dengan persentase $92,30 \%$ atau setara 
dengan 36 siswa yang tuntas dalam pembelajaran, sehingga diperoleh peningkatan sebesar 58,97\% dari hasil pembelajaran siklus pertama ke siklus yang ke-dua (Sitorus, 2017).

Berdasarkan wawancara serta hasil kajian teori dan literatur yang dilakukan peneliti dari beberapa penelitian relevan yang terdahulu, guru dan peneliti bermusyawarah bersama, hingga dipilihlah metode problem solving ini sebagai alternatif yang dapat digunakan untuk meningkatkan hasil belajar siswa pada soal cerita keliling dan luas bangun datar di sekolah dasar.

\section{METODE}

Metode dalam penelitian ini adalah penelitian tindakan kelas. Tempat penelitian adalah SDN 03 Koto Salak Kabupaten Dharmasraya dengan menjadikan seluruh siswa kelas IIIb SDN 03 Koto Salak sebagai subjek yang akan diteliti. Alur dalam penelitian ini menggunakan alur penelitian Kemmis dan Mc. Taggart yang terdiri dari empat langkah atau tahapan dalam pelaksanaan penelitian tindakan kelas, yaitu: perencanaan, pelaksanaan/tindakan, pengamatan/observasi, dan refleksi. Perencanaan penelitian yang dilakukan yaitu dengan mempersiapkan beberapa perlengkapan mengajar, seperti: a) membuat rancangan/alur pembelajaran b) menyiapkan Lembar Kerja Siswa (LKS) yang akan digunakan dalam proses belajar mengajar, c) menyediakan lembar observasi kegiatan belajar mengajar dan d) mempersiapkan media yang dibutuhkan untuk menunjang pembelajaran di kelas, serta e) menyiapkan soal tes/evaluasi pada siklus. Dengan melaksanakan pembelajaran sesuai RPP yang disusun penelitian ini dilakukan oleh peneliti dengan diawasi oleh dua orang observer yang terdisi dari pengamat peneliti dan pengamat siswa. Sedangkan pada setiap akhir tindakan diadakan evaluasi yang bertujuan mengukur tingkatan belajar siswa setelah mendapatkan tindakan menggunakan metode pembelajaran problem solving. Pada sesi observasi/pengamatan dilakukan bersamaan dengan pelaksanaan tindakan. Pada tahap ini peneliti bertindak sebagai pengajar/guru, sedangkan observasi/pengamatan dilakukan oleh dua orang pengamat. Pengamat pertama adalah seorang guru yang akan mengamati aktivitas guru/peneliti, pengamat ke dua adalah teman sebaya yang akan bertindak sebagi penngamat yang akan mengamati aktivitas siswa. Pada kegiatan pengamatan ini peneliti membagikan format lembar observasi menjadi dua bagian yaitu lembar observasi untuk aktifitas guru dan lembar observasi untuk aktivitas siswa. Setiap akhir satu tindakan dilakukan pengumpulan data terhadap tindakan yang telah dilakukan kemudian dianalisis untuk disimpulkan, dan dibandingkan dengan indikator keberhasilan pembelajaran dalam penelitian yang nantinya akan dijadikan pedoman untuk mengambil keputusan atas kegiatan selanjutnya. Sumber data dalam penelitian ini yaitu tes, dan hasil observasi/pengamatan. Tes yang dilakukan bertujuan untuk memperoleh data tentang hasil belajar siswa. Untuk mengukur pencapaian belajar maka diberikan alat untuk mengukur pencapaian belajar berupa pemberian soal tes evaluasi.

\section{HASIL DAN PEMBAHASAN}

Penelitian tindakan kelas ini dilaksanakan dalam dua siklus. Setiap siklus terdiri dari tiga kali pertemuan, dan dalam satu sisklus tersebut terdiri atas empat tahapan/langkah penelitian yang meilputi; kegiatan perencanaan, pelaksanaan atau tindakan, pengamatan/observasi, dan refleksi. Adapun yang diamati setiap siklus ialah aspek kegiatan guru, aspek kegiatan siswa dan hasil belajar. 
Tahap yang pertama yaitu perencanaan kegiatan. Beberapa perlengkapan mengajar yang perlu dipersiapkan dalam tahap ini, adalah: a) membuat rancangan/alur pembelajaran b) mempersiapkan lembar kerja peserta didik yang akan dipakai dalam proses belajar mengajar, c) menyiapkan lembar observasi kegiatan proses belajar mengajar yang akan dipakai oleh observer dalam mengamati dan memberi penilaian terhadap aktivitas peneliti dan aktivitas siswa saat proses pembelajaran berlangsung dalam satu siklus, dan d) mempersiapkan media pembelajaran, serta e) untuk mengukur pemerolehan belajar setelah memperoleh tindakan mengunakan maka perlu disipakan pula soal tes/evaluasi menyiapkan butir soal evaluasi untuk mengukur hasil kemampuan kognitif siswa setelah memperoleh tindakan menggunakan metode pembelajaran problem solving.

Tahap ke-dua yaitu pelaksanaan tindakan. Pada kegiatan awal, pembelajaran dibuka dengan meminta peserta didik melakukan rutinitas sebelum belajar yakni berdoa menurut agama dan kepercayaan masing-masing kemudian mengecek kedatangan siswa, dilanjutkan dengan mempersiapkan bebrapa peralatan mengajar seperti, gambar dan alat peraga dan memberikan pertanyaan-pertanyaan informatif yang bertujuan untuk mengetahui pengetahuan siswa yang kemudian dikaitkan dengan permasalahan bangun datar yang keberadaanya dekat/buming dalam kehidupan nyata. Siswa merespon guru dengan memberikan jawaban akan tetapi masih kelihatan malu-malu karena belum ada keberanian dan rasa percaya diri dalam diri siswa untuk menyampaikan gagasan ide dan pendapat di muka umum, maka dari itu kegiatan dilanjutkan oleh guru dengan menanamkan sikap percaya dirii berupa dorongan untuk terus belajar dalam menyampaikan gagasan di muka umum.
Pada kegiatan ini guru memperkenalkan kepada siswa tentang proses pembelajaran menggunakan metode problem solving. Adapun tahapannya adalah sebagai berikut:

\section{a. Adanya masalah}

Pada tahap ini diawali dengan penjelasan materi terkait cara menyelesaikan persoalan cerita pada pokok bahasan keliling dan luas bangun datar menggunakan metode problem solving yang diawali dengan pemahaman suatu permasalahan yang diberikan, kemudian mengumpulkan informasi atau keterangan, menentukan hasil perhitungan sementara, menguji kebenaran perhitungan sementara sampai pada tahap menyimpulkan permasalahan yang dipecahkan. Selanjutnya siswa dibagi ke dalam kelompok kecil terdiri dari tiga samapai empat siswa dan memberikan LKS kepada setiap kelompok.

b. Mencari data/keterangan

Pada tahap ini guru membimbing siswa mengumpulkan data berupa data yang diketahui dan yang ditanyakan di dalam soal lembar kerja siswa dengan cara guru membacakan soal cerita dengan seksama dan meminta siswa menggaris bawahi kunci pokok permasalahan yang tertera dalam penjabaran soal. Kegiatan selanjutnya, guru mengarahkan siswa secara berkelompok untuk dapat mencari solusi pemecahan soal, menghitung keliling dan luas persegi dan persegi panjang. Sebagian siswa langsung mendiskusikan dengan teman sekelompoknya, meskipun demikian masih terlihat beberapa siswa yang enggan mendiskusikan permasalahan dan lebih memilih ngobrol dengan teman yang lainnya. 
c. Menentukan jawaban sementara

Tahap ini guru mengarahkan siswa untuk menentukan dan menghitung jawaban sementara dan meminta perwakilan kelompok untuk mendemonstrasikan jawabannya ke depan kelas. Siswa yang bisa mengerjakan dengan penuh percaya diri menuliskan jawabannya di papan tulis dan menjelaskan secara lisan dengan bahasa sendiri.

d. Menguji kebenaran jawaban siswa

Guru mnegoreksi ulang apa-apa saja yang dituliskan siswa di papan tulis secara bersama-sama, kemudian mengapresiasi atas hasil kerja siswa tersebut.

Kegiatan yang dilakukan pada tahap penutupan pembelajaran ialah meminta siswa menyampaikan kesan dan pesan terhadap aktivitas selama belaja dan meminta siswa menyampaikan ringkasan terhadap materi yang baru saja selesai dipelajari. Selanjutnya guru memberikan informasi terkait pengujian/tes yang akan diadakan pada akhir siklus. Kemudian kegiatan pembelajaran ditutup dengan doa bersama.

Pelaksanaan pembelajaran yang sama juga dilakukan pada pertemuan siklus ke-II dimana dalam siklus tersebut dilakukan dalam tiga kali pertemuan. Untuk lebih detailnya berikut ini akan dipapar penjelasannya:

\section{a. Kegiatan awal}

Sesi pertama ini, proses belajar dibuka oleh guru dengan melaksanakan rutinitas sebelum belajar yakni membaca doa sesuai dengan kepercayaan masing masing, selanjutnya mengkondisikan masyarakat belajar serta dilanjutkan dengan pemeriksaan kehadiran siswa. Sebelum masuki kegiatan pokok belajar guru menyampaikan lintas pembelajaran yang lalu melalui pertanyan-pertanyaan. Siswa menunjukkan respon yang cukup baik, hal ini terbukti hampir semua siswa menunjuk tangannya, berebut ingin menjawab ketika diberi pertanyaan tentang langkah metode problem solving dalam memcahkan persoalan cerita matematik. Hal ini menunjukkan terjadinya perubahan sikap yang positif dilakukan pertemuanpertemuan sebelumnya.

b. Kegiatan inti

Guru memaparkan penjelasaan terkait materi cara-cara memcahkan persoalan cerita matematik pada topik bangun datar dengan cara mengaitkannya dengan dunia nyata siswa atau sesuai dengan kehidupan sosial. Siswa diharapkan dapat melaksanakan pembelajaran dengan lebih cermat dan teliti lagi untuk menyelesaikan soal cerita menggunakan langkah-langkah metode problem solving. Pada inti pembelajarannya aktivitas siswa dalam memecahkan persoalan tidak lagi dilakukan secara berkelompok. Pembelajaran dilakukan secara klasikal, guru hanya bertugas untuk mengarahkan dan membimbing siswa yang dirasa kurang memahami cara mengerjakan soal berdasarkan step dari metode problem solving serta pemberian stimulasi positif kepada siswa untuk senantiasa berusaha meyelesaikan permasalahan dalam soal cerita tersebut. Selanjutnya untuk memperkuat pemahamann siswa, dibagikanlah lembar kerja peserta didik kepada masing-masing siswa yang memuat sebuah persoalan cerita pada pokok pembahasan keliling dan luas bangun datar untuk dikerjakan mandiri oleh siswa yakni sendiri-sendiri. Setelah itu guru meminta 
siswa yang telah berhasil menyelesaikan soal untuk maju ke depan kelas memberikan penjelasan kepada teman-teman yang lainnya tentang cara penyelesaian dan cara memecahkan masalah soal cerita tersebut.

Siswa yang lainnya menyimak dan mengoreksi hasil pekerjaannya masingmasing dan kemudian merespon dan menanyakan hal-hal yang belum dipahami kepada teman yang mempresentasikan hasil kerjanya. Setelah selesai, diberikanlah penguatan dan pembenaran atas kerja siswa di depan kelas oleh guru.

\section{c. Kegiatan Akhir}

Guru mengulang kembali menjelaskan materi dengan cara mengambil garis besar pembelajaran. Menanggapi hal tersebut siswa kemudian menayakan hal-hal yang masih menjadi keraguan dalam belajar, selanjutnya guru memberikan penjelasan dan umpan balik agar siswa dapat menyimpulkan sendiri apa-apa saja yang telah dibelajarkan. Dilanjutkan dengan pemberian dorongan positif kepada siswa untuk terus bersemangat dalam belajar dan meningkatkan prestasi belajar.

Pelaksanaan kegiatan pembelajaran tersebut diharapkan dapat memberikan perubahan dan perbaikan pembelajaran yang apik terhadap peningkatan hasil belajar siswa dalam menyelesaikan soal cerita keliling dan luas bangun datar. Peranan guru merupakan kunci utama keberhasilan dalam pembelajaran. Sumarni (dalam Ariani \& Kenedi, 2018) mengungkapkan bahwa pendidik/guru harus memiliki kepiawaian dalam membuat rumusan tujuan pembelajaran yang jelas dengan harapan adanya perubahan yang akan dilakukan sehingga akan terbentuk pula perubahan prilaku yang berbeda dan lebih baik dari yang sebelumnya sebagai wujud dari hasil belajar. Melalui penerapan strategi dan metode pembelajaran serta melengkapi kelengkapan belajar lainya perubahan tersebut dapat dilakukan.

Tahap yang ke-tiga yaitu pengamatan (observasi) merupakan data kualitatif dalam penelitian ini, dilakukan untuk mengamati proses pembelajaran dengan menggunakan metode problem solving yang berlangsung di dalam kelas, dengan berpedoman pada lembar observasi. Kegiatan pengamatan dilakukan secara serempak dan beriringan dengan pelaksanaan tindakan. Pengamat mencermati apa saja kegiatan yang dilakukan peneliti dan siswa selama kegiatan belajar mengajar. apa yang terjadi dalam proses pembelajaran yang dilihat dari aktivitas yang dilakukan guru dan siswa.

Pengamatan yang dilakukan meliputi beberapa aspek pengamatan kegiatan yang dilakukan oleh guru/peneliti, siswa dan pengamatan hasil seperti yang tergambar dalam diagram berikut ini:

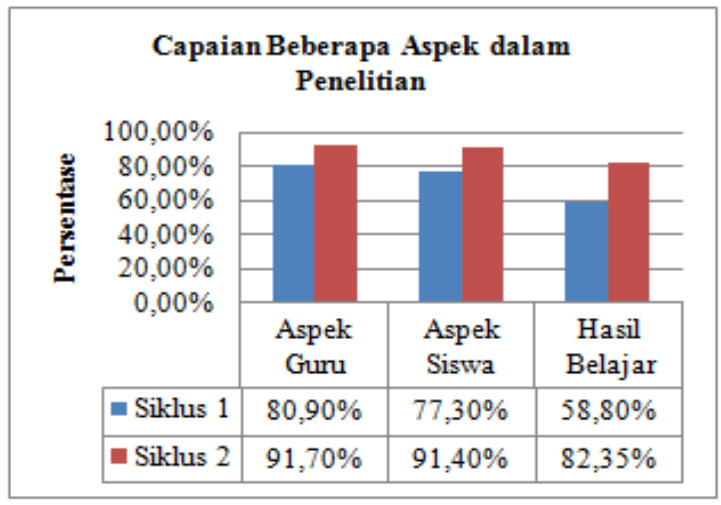

Gambar 1 Capaian Aspek dalam Penelitian

Melalui diagram di atas, didapatkan informasi bahwa pengamatan aspek guru melalui metode problem solving mengalami peningkatan dari siklus I yang semula sebesar 80,90\% dengan kategori baik menjadi sebesar $91,70 \%$ dengan kategori sangat baik pada sikus ke-dua. Pada pengamatan aspek siswa melalui metode problem solving, persentase skor yang diperoleh pada siklus 
pertama yakni $77,30 \%$ dengan kriteria baik dan mengalami peningkatan pada siklus ke-dua hingga diperoleh kriteria sangat baik dengan persentase skor $91,40 \%$. Begitu pula yang terjadi pada aspek pemerolehan hasil pembelajaran siswa melalui metode problem solving yang mengalami kenaikan dari persentase skor $58,80 \%$ kriterianya sangat kurang yang diperoleh pada siklus pertama kemudian skor mengalami kenaikan pada siklus ke-dua menjadi sebesar $82,35 \%$ dengan kriteria baik, seperti yang terlihat pada tabel pemerolehan hasil belajar di bawah ini:

Tabel 2. Hasil Belajar Siswa Pada Setiap Siklus

\begin{tabular}{cccc}
\hline Pertemuan & $\begin{array}{c}\text { Nilai } \\
\text { rata-rata }\end{array}$ & $\begin{array}{c}\text { Jumlah } \\
\text { Siswa } \\
\text { yang } \\
\text { Tuntas }\end{array}$ & $\begin{array}{c}\text { Persentase } \\
\text { Ketuntasan }\end{array}$ \\
\hline Siklus 1 & 72,29 & 10 & $58,80 \%$ \\
Siklus 2 & 86,29 & 14 & $82,35 \%$ \\
\hline
\end{tabular}

Sumber: Data Hasil Penelitian di SDN 03 Koto Salak Tahun Ajaran 2017/2018

Berdasarkan perolehan hasil pengamatan ini, maka dapat disimpulkan bahwasanya terjadi peningkatan dalam ketiga aspek pengamatan.

Tahap ke-empat merupakan kegiatan pengumpulan dan penyimpulan data yang sering disebut sebagai tahap refleksi ini dilakukan paling akhir setelah pelaksanaan tindakan dan pengamatan selesai. Tujuan dari tahap ini yaitu untuk mengetahui proses pembelajaran yang telah terjadi sehingga tidak terulang lagi pada kegiatan selanjutnya. Berdasarkan hasil refleksi pada sisklus I terlihat bahwa masih ditemukan beberapa kekurangan, diantaranya adalah;

a. Masih ada beberapa siswa yang terlihat bingung dalam menentukan harus menggunakan rumus persegi atau persegi panjang, ketika soal yang diberikan diwujudkan dalam soal cerita matematika. b. Masih ada beberapa siswa yang masih belum paham tentang bagaimana proses/langkah menyelesaikan soal cerita menggunakan metode problem solving karena penyampaian materi yang terlalu cepat.

c. Karena sistem pembelajaran dilakukan secara berkelompok ada sebagian siswa yang sering mengandalkan teman sekelompoknya dari pada harus berusaha bekerjasama untuk memecahkan persoalan dalam soal cerita

d. Ada beberapa siswa yang lalai dalam penggunaan waktu yang telah diberikan oleh guru sehingga banyak soal yang belum terjawab.

e. Perolehan belajar siswa belum maksimal, sehingga perlu dilakukan perubahan dan perbaikan pada proses pembelajaran dan dilanjutkan pada siklus selanjutnya.

\section{SIMPULAN}

Berdasarkan data penelitian yang didapat oleh peneliti selama kegiatan penelitian, maka peneliti dapat menyimpulkan bahwasannya pembelajaran yang dilaksanakan dengan mengikuti metode problem solving mampu memberi peningkatan pada tiga aspek pengamatan dalam penelitian yaitu; aktivitas/kegiatan yang dilakukan guru mengalami kenaikan dari 80,9\% ke 91,7\% . Aktivitas/kegiatan yang dilakukan siswa melalui metode problem solving mengalami kenaikan dari $77,3 \%$ ke $94 \%$. Begitu juga yang terjadi pada hasil belajar kognitif siswa yang dilaksanakan dengan menerapkan metode problem solving juga mengalami peningkatan. Berdasarkan hasil tes yang didapat pada siklus satu, rata-rata nilai siswa sebesar 72,29 dengan persentase ketuntasan $58,8 \%$ atau setara dengan 10 siswa yang tuntas pada pembelajaran matematika, kemudian nilai 
rata-rata siswa mengalami peningkatan pada siklus ke-dua yaitu menjadi 86,29 dengan persentase ketuntasan sebaesar $82,35 \%$ atau setara dengan 14 siswa yang tuntas dalam pembelajaran matematika khususnya pada pembahasan soal cerita matematika.

\section{DAFTAR PUSTAKA}

Anugraheni, I. (2019). Pengaruh Pembelajaran Problem Solving Model Polya Terhadap Kemampuan Memecahkan Masalah Matematika Mahasiswa. Jurnal Pendidikan (Teori Dan Praktik), 4(1), 1. https://doi.org/10.26740/jp.v4n1.p1-6

Ariani, Y., \& Kenedi, A. K. (2018). Model Polya Dalam Peningkatan Hasil Belajar Matematika Pada Pembelajaran Soal Cerita Volume Di Sekolah Dasar. Jurnal Inspirasi Pendidikan, $\quad$ 8(2), 25-36. https://doi.org/10.21067/jip.v8i2.2520

BSNP. 2006. Panduan Penyusunan Kurikulum Tingkat Satuan Pendidikan Jenjang Pendidikan Dasar dan Menengah. Jakarta: Badan Standar Nasional Pendidikan

Daharnis, D., Nirwana, H., Ifdil, I., Afdal, A., Ardi, Z., Taufik, T., Erlamsyah, E., Alizamar, A., Fadli, R. P., Erwinda, L., Zola, N., Refnadi, R., \& Fikriyanda, F. (2019). Mathematics anxiety among prospective elementary school teachers and their treatment. Journal of Physics: Conference Series, 1157(4), 1-8. https://doi.org/10.1088/17426596/1157/4/042089

Depdiknas. 2006. Peraturan Mentri Pendidikan Nasional Republik Indonesia, Nomor 22 Tahun 2006, Tentang Standar Isi Untuk Satuan Pendidikan Dasar Dan Menengah.Jakarta: Depdiknas

Djamarah, Syaiful Bahri. 2010. Strategi Belajar Mengajar. Jakarta: PT Rineka Cipta

Fitri, A. (2016). Penerapan Pendekatan Pemecahan Masalah Matematika Dengan Media Prentasi Untuk Meningkatkan Kemampuan Menyelesaikan Soal Cerita. Jurnal Sekolah Dasar, 1(1), 16-37. Jurnal Sekolah Dasar, ISSN 2528-2883

Hidayat, W., \& Sariningsih, R. (2018). Kemampuan Pemecahan Masalah Matematis dan Adversity Quotient Siswa SMP Melalui Pembelajaran Open Ended. Jurnal JNPM (JurnalNasional Pendidikan Matematika), 2(1), 109. https://doi.org/10.1016/S0962-

\section{9(96)90008-8}

Husna, \& Burais, F. F. (2019). Penerapan Pendekatan Problem Solving untuk Meningkatkan Kemampuan Pemecahan Masalah Matematis Siswa Berdasarkan Level Siswa. Al-Ishlah: Jurnal Pendidikan, 1(1), 11-20.

Imelda, I. (2018). Penerapan Metode Problem Solving Dalam Meningkatkan Kemampuan Pemecahan Masalah Pada Mata Kuliah Aljabar Dan Trigonometri. MES: Journal of Mathematics Education and Science, 3(2), 159-166. https://doi.org/10.30743/mes.v3i2.496

Pagarra, H. (2016). Peningkatan Hasil Belajar Matematika Melalui Model Pembelajaran Problem Solving Pada Siswa Kelas V SDN Kakatua Kecamatan Marisokota Makassar. Jurnal Publikasi Pendidikan, 6(3), 203-213. https://doi.org/10.26858/publikan.v6i3.2276

Sakadius, M. Y., Tahmid, S., \& Uliyanti, E. (2017). Penggunaan Metode Problem Solving untuk Meningkatkan Kemampuan Siswa Mengerjakan Soal Cerita Pada Pembelajaran Matematika. 1-12.

Sitorus, R. (2017). Penerapan Metode Problem Solving Untuk Meningkatkan Hasil Belajar Siswa Pada Pembelajaran Matematika di Kelas IV SD Negeri Mdan Estate. 140-150.

Taufina, T., Chandra, C., Fauzan, A., \& Ilham Syarif, M. (2019). Development of Statistics in Elementary School Based RME Approach with Problem Solving for Revolution Industry 4.0. International Conference on Education and Technology, 382(Icet), 716721. https://doi.org/10.2991/icet-19.2019.172

Uyani, S. (2016). Penerapan Model Problem Solving Dalam Meningkatkan Kemampuan Hot (Higher Order Thinking) Siswa SDN Banyu Landas. Jurnal Vidya Karya, 31(1), 91-104. https://doi.org/10.20527/jvk.v31i1.3978 